\title{
Kompetensi Pemimpin Membangun Ruh Al-Jama'ah Dalam Sistem Manajemen Pendidikan Islam
}

\author{
Ahmad Syukri Saleh \\ Universitas Islam Negeri Sulthan Thaha Saifuddin Jambi \\ Email: ahmadsyukrisaleh65@gmail.com \\ Kasful Anwar US \\ Universitas Islam Negeri Sulthan Thaha Saifuddin Jambi \\ Email: kasfulanwarus@gmail.com \\ M. Kamal \\ Universitas Islam Negeri Sulthan Thaha Saifuddin Jambi \\ Email: kamalmpi75@gmail.com
}

\begin{abstract}
The difficulty of finding an ideal leader, one of which is caused by the assumption that the position is considered a "gift" that is obtained with a little struggle or in a dishonorable way. The figure of a leader who can resolve various shocks that arise, namely a leader with character. A leader must have the ability to influence others, be authoritative, and visionary. There are six integral functions that must be carried out by a leader, namely: preserve religion, preserve the soul, preserve reason, preserve the continuity of generations, preserve property, and preserve honor. Managing organizations with a human behavior approach (human behavior aproach) needs to be done. In the behavioral approach (behavioral approach) tries to identify the typical behavior of the leader in his activities to influence group members or followers. This leader's behavior can be oriented to organizational tasks or to relationships with group members. People-oriented leadership behavior (Concern for People) is the focus of discussion that the authors consider to have closeness of meaning and function operationally in the efforts of leaders to build the spirit of al-Jama'ah (the spirit of teamwork). The success of an organization to achieve its goals is strongly influenced by the capability of leaders in managing human resources with the spirit of teamwork (ruhul jama'ah). To increase the effectiveness of his leadership, leaders can use the influence of: (a) rational persuasion, (b) exchange tactics, (c) legitimate requests, (d) pressure tactics, and (e) personal appeals. Including; (f) pay attention to the needs of subordinates (Abraham Maslow's theory), (g) create an atmosphere of mutual trust between subordinates with leaders and subordinates with subordinates, (g) put sympathy towards subordinates as part of the organization, (h) show the friendship with subordinates, (i) and prioritizes self-direction, self-discipline, selfcontrol.
\end{abstract}

Keyword: Leader Competence, The Spirit of Teamwork, Rubul Jama'ah.

Nur El-Islam, Volume 6, Nomor 2, Oktober 2019 


\section{Abstrak}

Sulitnya menemukan sosok pemimpin yang ideal, salah satumya disebabkan oleh anggapan bahwa jabatan dianggap sebagai "anugerah" yang didapat dengan sedikit perjuangan atau dengan cara-cara yang tidak terhormat. Sosok pemimpin yang dapat menyelesaikan berbagai gejolak yang muncul, yaitu seorang pemimpin yang berkarakter. Seorang pemimpin harus memiliki kemampuan untuk memengaruhi orang lain, berwibawa, dan visioner. Ada enam fungsi secara integral yang harus dilaksanakan oleh seorang pemimpin, yaitu: memelihara agama, memelihara jiwa, memelihara akal, memelihara kesinambungan generasi, memelihara harta, dan memelihara kehormatan. Mengelola organisasi dengan pendekatan prilaku manusia (buman behavior aproach) perlu dilakukan. Dalam pendekatan keperilakuan (behavioral approach) mencoba mengidentifikasi perilaku yang khas dari pemimpin dalam kegiatannya untuk mempengaruhi anggota-anggota kelompok atau pengikutnya. Perilaku pemimpin ini dapat berorientasi pada tugas keorganisasian ataupun pada hubungan dengan anggota kelompoknya. Perilaku kepemimpinan yang berorientasi pada orang (Concern for People) merupakan fokus bahasan yang penulis anggap memiliki kedekatan makna dan fungsi secara operasional pada upaya pemimpin membangun rub al-jama'ah (spirit kerjasama tim/team work). Keberhasilan organisasi mencapai tujuannya sangat dipengaruhi oleh kapabilitas pemimpin dalam mengelola sumber daya manusia dengan spirit kerjasama tim (rubul jama'ab). Untuk meningkatkan efektifitas kepemimpinannya, pemimpin dapat menggunakan pengaruh: (a) rational persuasion, (b) exchange tactics, (c) legitimate request, (d) pressure tactics, dan (e) personal appeals. Termasuk juga; (f) memperhatikan kebutuhan bawahan (teori Abraham Maslow), (g) menciptakan suasana saling percaya antar bawahan dengan pimpinan dan bawahan dengan bawahan, (g) menaruh simpati terhadap bawahan sebagai bagian dari organisasi, (h) memperlihatkan sisi persahabatan dengan bawahan, (i) dan mengutamakan pengarahan diri, mendisiplin diri, mengontol diri.

Kata kunci: Kompetensi Pemimpin, Kerjasama Tim, Rubul Jama'ah.

\section{PENDAHULUAN}

\section{A. Latar Belakang}

Kepemimpinan merupakan suatu konsep abstrak, tetapi hasilnya nyata. Kadangkala kepemimpinan mengarah pada seni, tetapi seringkali pula berkaitan dengan ilmu. Pada kenyataannya, kepemimpinan merupakan seni sekaligus ilmu. Ada banyak definisi mengenai kepemimpinan, bergantung pada perspektif yang digunakan.

Dalam organisasi ataupun lembaga, keberadaan seorang pemimpin harus menjadi perhatian yang serius, karena keberhasilan organisasi ataupun Lembaga dalam mencapai tujuannya sangat 
dipengaruhi oleh peran dan kompetensi seorang pemimpin. Pemimpin harus tampil bukan hanya menjadi seorang manajer, tetapi lebih kepada seorang leader yang mengarahkan, menggerakkan dan memotivasi bawahannya melaksanakan tugas dan bekerjasama dalam mencapai tujuan.

Secara sederhana, yang disebut pemimpin adalah apabila berkumpul tiga orang atau lebih kemudian salah seorang di antara mereka "mengajak" untuk melakukan suatu pekerjaan maka orang tersebut telah melakukan "kegiatan memimpin" karena ada unsur "mengajak" dan mengoordinasi dan ada kegiatan serta sasarannya. Seorang pemimpin harus melakukan berbagai fungsi kepemimpinannya. Fungsi kepemimpinan, yaitu: menentukan tujuan, menjelaskan, melaksanakan, memilih cara yang tepat, memberikan, serta merangsang para anggota untuk bekerja. ${ }^{1}$ Oleh karena itu, konsep kepemimpinan minimal harus mencakup tiga unsur, yaitu ada seorang pemimpin yang memimpin, mempengaruhi, dan memberikan bimbingan; ada anggota (bawahan) yang dikendalikan, ada tujuan yang diperjuangkan melalui serangkaian kegiatan.

Fenomena yang tampak di lembaga pendidikan ataupun Instansi pemerintahan kadangkala pengukuran tingkat keberhasilan lebih ditekankan pada kemampuan instansi tersebut dalam menyerap anggaran, suatu instansi akan dinyatakan berhasil apabila dapat menyerap $100 \%$ anggaran yang disediakan pada tahun yang bersangkutan, meskipun kenyataan dilapangan menunjukkan hasil (outcomes), manfaat (benefits) dan dampak (impacts) yang dicapai dari pelaksanaan program tersebut masih berada jauh di bawah standar, padahal tolak ukur keberhasilan lembaga pendidikan itu terletak pada kemampuan menjalankan fungsi manajemen dengan baik.

Kesanggupan (ability) dan kompetensi menjalankan fungsi manajemen merupakan syarat mutlak yang harus dimiliki oleh seorang pemimpin. Secara umum, rumusan Kompetensi menurut yaitu:

Competence $=$ Knowledge + experience + ability

${ }^{1}$ Endin Nasrudin, Psikologi Manajemen, (Bandung: Pustaka Setia, 2018), h. 55. 
Knowledge comprises a co-worker's training and qualifications. Experience is framed by time and work content. Ability refers to the capacity to utilize knowledge and experience to solve problems. Pengetahuan dapat diperoleh dari pelatihan. Pengalaman dibingkai oleh waktu dan konten kerja. Kemampuan mengacu pada kapasitas untuk memanfaatkan pengetahuan dan pengalaman untuk memecahkan masalah. Selain itu, gaya kepemimpinan turut serta mempengaruhi kehidupan organisasi kearah yang lebih humanis, karena sumber daya manusia yang menjadi salah satu unsur organisasi dan merupakan urat nadi bagi keberlangsungan organisasi merupakan salah satu sasaran aktivitas kepemimpinan di samping sumber daya lainnya. ${ }^{2}$

Sulitnya menemukan sosok pemimpin yang ideal, salah satumya disebabkan oleh anggapan bahwa jabatan dianggap sebagai "anugerah" yang didapat dengan sedikit perjuangan atau dengan caracara yang tidak terhormat. Sosok pemimpin yang dapat menyelesaikan berbagai gejolak yang muncul, yaitu seorang pemimpin yang berkarakter. Seorang pemimpin harus memiliki kemampuan untuk memengaruhi orang lain, berwibawa, dan visioner. Ada enam fungsi secara integral yang harus dilaksanakan oleh seorang pemimpin, yaitu: memelihara agama, memelihara jiwa, memelihara akal, memelihara kesinambungan generasi, memelihara harta, dan memelihara kehormatan.

Mengelola organisasi dengan pendekatan prilaku manusia (human behavior aproach) perlu dilakukan. Dalam pendekatan keperilakuan (behavioral approach) mencoba mengidentifikasi perilaku yang khas dari pemimpin dalam kegiatannya untuk mempengaruhi anggota-anggota kelompok atau pengikutnya. Perilaku pemimpin ini dapat berorientasi pada tugas keorganisasian ataupun pada hubungan dengan anggota kelompoknya.

Hasil penelitian yang dilakukan oleh Ohio State University, dibedakan adanya dua macam perilaku kepemimpinan yaitu; Initiating Structure and Consideration. Hasil penelitian tersebut, didukung oleh

${ }^{2}$ Karlof and Lovingsson, The $A-Z$ of Management Concepts and Models, (India: Replika Press, 2005), h. 110. 
hasil dari Survey Research Center Michigan University, dengan dua macam perilaku kepemimpinan yaitu job centered production orientation dan employee centered (employee orientation) yang memiliki pengertian yang sama dengan yang dikeluarkan oleh Ohio State University. Teori yang lain memberikan gambaran tentang model orientasi kepemimpinan dalam bentuk perilaku yang diperlihatkan, yaitu teori Managerial Grid dari Robert K. Blake and James s. Mouton yang merdasarkan kepada dua model orientasi kepemimpinan yaitu: Concern for Production and Concern for People, penekanan pada produksi dan tugas dan penekanan pada hubungan antar individu. ${ }^{3}$

\section{B. Fokus Pembahasan}

Perilaku kepemimpinan yang berorientasi pada orang (Concern for People) merupakan fokus bahasan yang penulis anggap memiliki kedekatan makna dan fungsi secara operasional pada upaya pemimpin membangun ruh al-jama'ah (spirit kerjasama tim/team work). Keberhasilan organisasi mencapai tujuannya sangat dipengaruhi oleh kapabilitas pemimpin dalam mengelola sumber daya manusia dengan spirit kerjasama tim (ruhul jama'ah). Lebih spesifik artikel ini memaparkan hal-hal; 1) organisasi dan fungsi manajemen dalam organisasi, 2) kepemimpinan, kompetensi, dan gaya kepemimpinan, 3) kompetensi pemimpin membangun Ruh al-Jama'ah.

\section{PEMBAHASAN}

\section{A. Fungsi Manajemen dalam Organisasi}

Mungkin kita pernah mendengar perumpamaan orang-orang yang bekerja dalam tim itu seperti bangunan rumah yang memiliki banyak bagian. Mulai dari atap sampai tanaman rambat di halaman berperan sesuai fungsinya masing-masing, tidak semua harus menjadi atap yang terkena panas atau hujan demi melindungi bagian lainnya, tidak semua harus menjadi tiang penyangga yang kuat, tidak juga semua harus menjadi pagar yang terekspose dunia luas, melindungi para penghuni rumah dari luar, tapi perlu ada yang menjadi pintu dan

${ }^{3}$ Minnah El Widdah, Kepemimpinan Berbasis Nilai dan Pengembangan Mutu Madrasah, (Bandung: Alfabeta, 2012), h. 47. 
jendela yang mengatur sirkulasi, ada pula yang menjadi batu-bata dan Pondasi yang walaupun mereka tidak kelihatan. Tanpa adanya dua hal itu, apa jadinya sebuah bangunan?.

Narasi di atas merupakan gambaran dalam konteks pengelolaan sebuah organisasi. Defenisi organisasi yang ditawarkan Narayan dan Nath dalam Akdon, "an organization can be defined as an arena where human beings come together to perform complex tasks, so as to fulfill common goals" organisasi dapat diartikan sebagai suatu perserikatan orang-orang yang masing-masing diberi peranan tertentu dalam melaksanakan kegiatan sesuai dengan peranan tersebut bersama-sama secara terpadu mencapai tujuan yang telah ditentukan bersama. Organisasi sebagai arena perserikatan orang-orang yang beraktivitas, aktivitas orang-orang tersebut terarah pada pencapaian tujuan. ${ }^{4}$

Sebagai kumpulan orang-orang yang beraktivitas, suatu organsisasi perlu dikelola dengan manajemen, diarahkan dan dimotivasi dengan menerapkan fungsi leadership seorang pemimpin agar seluruh elemen yang ada di dalamnya berjalan on the track mencapai tujuan organisasi secara efektif dan efesien. Manajemen organsiasi berbicara tentang bagaimana mendayagunakan berbagai sumber (manusia, sarana dan prasarana, serta media lainnya) secara optimal, relevan, efektif dan efesien guna menunjang pencapaian tujuan.

Pemahaman terhadap teori manajemen menjadi kebutuhan yang primer dalam menjalankan organsiasi dengan baik. Teori-teori manajemen bahkan dapat membantu para manajer dalam mengambil keputusan yang tepat, menentukan sikap dan tindakan yang sesuai dengan konteks persoalan yang dihadapi organisasi, menangkap peluang dan kemungkinan yang akan terjadi, serta memahami bagaimana cara manajemen bekerja pada manusia, lingkungan, dan sebaliknya.

Manajemen bersifat universal karena menggunakan kerangka ilmu pengetahuan yang bersifat sistematis yang mencakup kaidahkaidah atau rumusan-rumusan, prinsip-prinsip dan konsep-konsep.

${ }^{4}$ Akdon, Strategic Management for Educational Management, (Bandung: Alfabeta, 2009), h. 43. 
Jadi bila ada seorang manajer mempunyai dan menggunakan pengetahuan dasar mengenai manajemen serta dapat menerapkan ilmu tersebut pada bentuk, situasi dan kondisi yang ada, maka manajer tersebut dapat menjalankan fungsi-fungsi manajerial yang ada secara efektif dan efesien. "Efektif berarti bahwa tujuan dapat dicapai sesuai dengan perencanaan, sementara efisien berarti bahwa tugas yang ada dilaksanakan secara benar, terorganisir, dan sesuai dengan jadwal". ${ }^{5}$

Secara praktis, manajemen dibutuhkan dan diperlukan untuk semua tipe kegiatan yang diorganisir dan dalam semua bentuk kegiatan organisasi, dimana ada orang bekerjasama dalam mencapai suatu tujuan disitulah manajemen diperlukan dan dibutuhkan. Macam bentuk dari organisasi sebenarnya sama dalam menjalankan manajemennya (dalam hal ini fungsi manajemen), karena fungsi manajemen sifatnya universal, sama baik untuk perusahaan kecil, besar maupun multinasional, yaitu melakukan perencanaan (planning), pengorganisasian (organizing), penggerakan sumber daya (actuating), dan pengendalian (controlling) disingkat POAC.

Ada yang menyebut bahwa POAC di atas: (planning, Organizing, Actuating and Controlling) sebagai fungsi manajemen. Weihrich dan Koontz dalam Musfah menyebutkan fungsi manajemen menjadi lima bagian: planning, organizing, staffing, leading, and controlling (POSLC). Dalam bukunya Manajemen Program Pendidikan, Sudjana, membaginya menjadi Planning, Organizing, Motivating, Comforming (pembinaan), Evaluating, and Developing (POMCED). Jadi paling tidak ada tiga model fungsi manajemen. ${ }^{6}$

Table fungsi manajemen

\begin{tabular}{|l|l|}
\hline POAC & planning, Organizing, Actuating and Controlling \\
\hline POSLC & planning, organizing, staffing, leading, and controlling \\
\hline POMCED & $\begin{array}{l}\text { Planning, Organizing, Motivating, Comforming } \\
\text { (pembinaan), Evaluating, and Developing }\end{array}$ \\
\hline
\end{tabular}

${ }^{5}$ Sarinah, Pengantar Manajemen, (Yogyakarta: Deepublish: 2017), h. 1.

${ }^{6}$ Musfah, Manajemen Pendidikan, Teori, Kebijakan, dan Praktek, (Jakarta: Kencana, 2017), h. 2 . 


\section{Planning (Perencanaan).}

Sukses sebuah tindakan atau program dipengaruhi oleh mutu langkah awal yang dilakukan. Seorang manajer harus memahami kemana dan untuk apa serta langkah-langkah apa saja yang harus dilakukan untuk mencapai tujuan kerja organisasi misalnya. Dalam perencanaan, pemimpin atau manajer memutuskan; tindakan apa yang harus dilakukan, apa sebabnya tindakan tersebut harus dilakukan, di mana tindakan tersebut dilakukan, kapan melakukannya, siapa yang akan melakukan tindakan tersebut, dan bagaimana cara melakukannya.

2. Organizing/Staffing (Pengorganisasian).

Pengorganisasian dapat diartikan sebagai kegiatan mengoordinasi sumber daya, tugas, dan otoritas di antara anggota organisasi agar tujuan organisasi dapat dicapai dengan cara yang efisien dan efektif. Terry and Rue, mendefenisiskan Organizing (mengorganisir) adalah proses pengelompokan kegiatan-kegiatan untuk mencapai berbagai tujuan dan penugasan setiap kelompok kepada seorang manajer yang mempunyai kekuasaan, yang perlu untuk mengawasi anggota-anggota kelompok. Pengorganisiran dilakukan untuk menghimpun dan mengatur semua sumber-sumber yang diperlukan termasuk manusia sehingga pekerjaan yang dikehendaki dapat dilaksanakan dengan baik. ${ }^{7}$

\section{Leading/Actuating (Pengarahan dan Pelaksanaan ).}

Setelah struktur organisasi ditetapkan, orang-orangnya ditentukan. Langkah selanjutnya adalah membuat bagaimana orangorang tersebut bekerja untuk mencapai tujuan organisasi. Manajer perlu "mengarahkan" orang-orang tersebut. Lebih spesifik lagi pengarahan meliputi kegiatan memberi pengarahan (directing), memengaruhi orang lain (influencing), dan memotivasi orang tersebut untuk bekerja (motivating).

G.R. Terry mengemukakan dan ditulis oleh Badrudin "Actuating is setting all members of the group to want to achieve and to strike to

\footnotetext{
${ }^{7}$ Terry and Rue, Dasar-dasar Manajemen, (Jakarta: Bumi Aksara, 2019), h. 70.
} 
achieve the objective willingly and keeping with the managerial planning and organizing efforts. (pengarahan adalah membuat semua anggota kelompok agar mau bekerja sama dan bekerja secara ikhlas serta bergairah untuk mencapai tujuan sesuai dengan perencanaan dan usaha-usaha pengorganisasian). Koontz dan O'Donnel dalam Badrudin, mengatakan "directing and leading are the interpersonal aspects of managing by which subordinate are lead to understand and contribute effectively and efficiency to the attainment of enterprise objectives". (pengarahan adalah hubungan antara aspek-aspek individual yang ditimbulkan oleh adanya pengaturan terhadap bawahan-bawahan untuk dapat dipahami dan pembagian kerja yang efektif dan efesien untuk tujuan perusahaan yang nyata). ${ }^{8}$

\section{Controlling (Pengendalian)}

Elemen terakhir proses manajemen adalah pengendalian. Sistem pengawasan harus dibuat sebaik mungkin dan komprehensif. Di samping Control by System, seorang pemimpin harus memberikan warning kepada bawahannya terhadap situasi kerja yang sudah tidak sesuai dengan yang direncanakan. Dalam hal ini, Louis E. Boone dan David L. Kurtz dalam Sarinah memberikan rumusan tentang pengawasan sebagai: "the process by which manager determine wether actual operation are consistent with plans. ${ }^{9}$

Controlling atau pengawasan dan pengendalian (wasdal) adalah proses untuk mengamati secara terus menerus pelaksanaan kegiatan sesuai dengan rencana kerja yang sudah disusun dan mengadakan koreksi jika terjadi. Controlling atau pengawasan adalah fungsi manajemen dimana peran dari personal yang sudah memiliki tugas, wewenang dan menjalankan pelaksanaannya perlu dilakukan pengawasan agar supaya berjalan sesuai dengan tujuan, visi dan misi perusahaan. ${ }^{10}$

Pengendalian bertujuan melihat apakah kegiatan organisasi sesuai dengan rencana. Manajer harus selalu memonitor kemajuan

\footnotetext{
${ }^{8}$ Badrudin, Dasar-dasar Manajemen, (Bandung: Alfabeta, 2015), h. 152.

${ }^{9}$ Sarinah, Pengantar Manajemen, h. 16.

${ }^{10}$ Ibid, h. 105.
} 
organisasi. Fungsi pengendalian meliputi empat kegiatan: (1) menentukan standar prestasi, (2) mengukur prestasi yang telah dicapai selama ini, (3) membandingkan prestasi yang telah dicapai dengan standar prestasi, dan (4) melakukan perbaikan jika ada penyimpangan dari standar prestasi yang telah ditentukan. Kemudian, kembali lagi ke fungsi perencanaan untuk periode berikutnya.

\section{B. Kepemimpinan, Gaya, dan Kompetensi Pemimpin.}

\section{Kepemimpinan}

Banyak defenisi mengenai kepemimpinan yang dikemukakan oleh para pakar berdasarkan sudut pandang masing-masing, tergantung perspektif yang digunakan. Kepemimpinan dapat didefenisikan berdasarkan penerapannya pada bidang pendidikan militer, olah raga, bisnis, pemerintahan, industri, dan bidang-bidang lainnya.

Ada dua istilah yang digunakan untuk kata pemimpin dalam konteks manajemen organisasi, yaitu manager dan leader. Penggunaan kata manajer lebih banyak dipergunakan penyebutannya untuk pemimpin suatu perusahaan daripada penyebutan leader (pemimpin), dan kata leadership berarti kepemimpinan. "Manajer adalah pimpinan atau pemimpin suatu organisasi. Dalam organisasi, istilah manajer digunakan dengan berbagai istilah, yaitu direktur, rektor, pimpinan, ketua, kepala, presiden, dan sebagainya. Dalam Lembaga Pendidikan, ada yang disebut dengan rector, direktur, ketua umum, kepala sekolah (mudir 'am). Rektor, dekan, ketua jurusan, direktur pascasarjana, ketua program studi diperguruan tinggi, dan ketua untuk sekolah tinggi, kepala sekolah untuk sekolah tingkat dasar sampai dengan tingkat menengah dan tingkat atas atau SLTP, Tsanawiyah, SMU, dan Aliyah. ${ }^{11}$

Seorang manajer adalah orang yang menggunakan wewenang dan kebijaksanaan organisasi/perusahaan untuk menggerakkan staf atau bawahannya mencapai tujuan yang telah ditetapkan. Karena itu, seorang manajer biasanya bertugas untuk mengelola sumber daya fisik, yang berupa capital (modal), human skill (keterampilan-

${ }^{11}$ Andi Rasyid Pananrangi, Manajemen Pendidikan, (Jakarta: Celebes Media Perkasa, 2017), h. 46. 
keterampilan manusia), row material (bahan mentah), dan technology, agar dapat melahirkan produktivitas, efesiensi, tepat waktu (sesuai dengan rencana kerja), dan dan kualitas Berbeda halnya dengan seorang pemimpin (leader), yang lebih memfokuskan pada visi. Ia berusaha mengajak dan memotivasi staf atau bawahannya untuk bersama-sama mencapai tujuan yang telah ditetapkan. Karena itu seorang pemimpin (leader) biasanya berusaha mengelola sumbersumber emosional dan spiritual, yang berupa: values (nilai-nilai), commitment (keberpihakan), dan aspiration (aspirasi) staf atau bawahannya, agar dapat melahirkan kebanggaan dan kepuasan dalam bekerja. Menurut teori manajemen, bahwa manajer yang sukses adalah manajer yang memiliki unsur kepemimpinan (leadership) dan mampu menerapkan serta mengembangkannya, dengan kata lain, manajer yang mampu bertindak sebagai pemimpin (manager as a leader). ${ }^{12}$

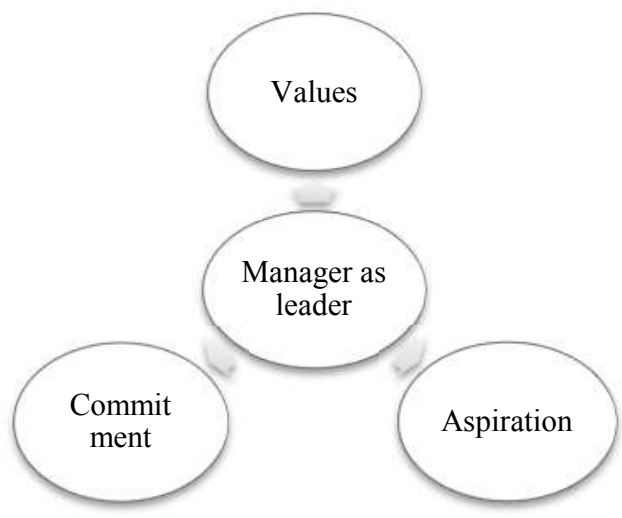

Ordway Tead dalam Badrudin, memberikan rumusan Leadership is the activity influencing people to cooperate some good which they come to find desirable, (Kepemimpinan adalah suatu kegiatan mempengaruhi orang lain untuk bekerja sama guna mencapai tujuan tertentu yang diinginkan. Hal senada dikemukakan oleh Slamet Santosa yang mendefenisikan kepemimpinan sebagai usaha mempengaruhi anggota

${ }^{12}$ Muhaimin dkk, Manajemen Pendidikan, Aplikasinya dalam Penyusunan Rencana Pengembangan Sekolah/Madrasah, (Jakarta: PT Kharisma Putra Utama, 2009), h. 4. 
kelompok agar mereka bersedia menyumbangkan kemampuannya lebih banyak dalam mencapai tujuan kelompok yang disepakati. ${ }^{13}$

Kepemimpinan adalah rangkaian kegiatan penataan berupa kemampuan mempengaruhi perilaku orang lain dalam situasi tertentu agar bersedia bekerjasama untuk mencapai tujuan yang ditetapkan. Kepemimpinan (leadership) memiliki pengertian sebagai kemampuan yang harus dimiliki oleh seorang pemimpin (leader) tentang bagaimana menjalankan kepemimpinannya (to lead) sehingga bawahan dapat bergerak sesuai dengan yang diinginkan dalam mencapai tujuan yang ditetapkan sebelumnya. Bergeraknya orangorang harus mengikuti jalur tujuan organisasi yang hendak dicapai dan bukan merupakan hal semu dari kepemimpinannya itu sendiri, karena bagaimanapun pemimpin itu adalah bagian dari anggota organisasi itu sendiri. Adapun pergerakan dalam pencapaian tujuan adalah legitimasi dari sebuah kekuasan yang dimiliki oleh pemimpin, karena bukan hanya sebuah simbol atau kedudukan semata.

\section{Gaya Kepemimpinan}

Gaya kepemimpinan dari seorang pemimpin akan berbeda-beda. Perbedaan tersebut dapat dianalisis dari fungsi kepemimpinan mereka ketika menghadapi bawahan, karyawan, atau pengikutnya. Kepemimpinan akan berlangsung efektif bilamana pemimpin mampu memenuhi fungsinya meskipun dalam kenyataannya tidak semua tipe kepemimpinan memberikan peluang yang sama untuk mewujudkannya. Dalam hubungan itu sulit untuk dibantah bahwa setiap proses kepemimpinan juga akan menghasilkan situasi sosial yang berlangsung di dalam kelompok atau organisasi masing-masing. Untuk itu, setiap pemimpin harus mampu menganalisis situiasi sosial kelompok atau organisasinya yang dapat dimanfaatkan dalam mewujudkan fungsi kepemimpinan dengan kerja sama dan bantuan orang-orang yang dipimpinnya.

Konsep seorang pemimpin dari kekuasaan yang memproyeksikan diri dalam bentuk sikap memimpin, tingkah laku, dan sifat kegiatan pemimpin yang dikembangkan dalam organisasinya akan

${ }^{13}$ Badrudin, Dasar-dasar Manajemen, h. 163. 
memengaruhi situasi kerja, semangat kerja anggota-anggota staf, sifat hubungan kemanusiaan diantara sesamanya, dan kualitas kerja yang mungkin dapat dicapai oleh Lembaga organisasi tersebut. Oleh karena itu, gaya dan type kepemimpinan dapat diklasifikasikan menjadi empat type, yaitu otoriter, laissez-faire, demokrasi, dan pseudo demokrasi.

\section{a. Tipe Otoriter}

Tipe otoriter adalah gaya pemimpin yang memusatkan segala keputusan dan kebijakan yang diambil dari dirinya sendiri secara penuh. Segala pembagian tugas dan tanggungjawab dipegang oleh pemimpin yang otoriter tersebut, sedangkan para bawahan hanya melaksanakan tugas yang telah diberikan. Pemimpin otoriter hanya dibatasi oleh undang-undang. Bawahan hanya bersifat sebagai pembantu, kewajiban bawahan hanyalah mengikuti dan menjalankan perintah dan tidak boleh membantah atau mengajukan saran, mereka harus patuh dan setia kepada pemimpin secara mutlak.

Pemimpin yang otoriter tidak menghendaki rapat atau musyawarah. Setiap perbedaan di antara anggota kelompoknya diartikan sebagai kelicikan, pembangkangan, atau pelanggaran disiplin terhadap perintah atau instruksi yang telah diberikan. Inisiatif dan daya pikir anggota sangat dibatasi sehingga tidak diberi kesempatan untuk mengeluarkan pendapatnya. Pengawasan bagi pemimpin yang otoriter hanyalah berarti mengontrol, apakah segala perintah yang telah diberikan ditaati atau dijalankan dengan baik oleh anggotanya. Mereka melaksanakan inspeksi, mencari kesalahan, dan meneliti orang-orang yang dianggap tidak taat kepada pemimpin, kemudian orang-orang tersebut diancam dengan hukuman, dipecat, dan sebagainya.

Sebaliknya, orang-orang yang berlaku taat dan menyenangkan pribadinya, dijadikan anak emas, bahkan diberi penghargaan. Kekuasaan berlebih ini dapat menimbulkan sikap menyerah tanpa kritik dan kecenderungan untuk mengabaikan perintah dan tugas jika tidak ada pengawasan langsung. Selain itu, dominasi yang berlebihan mudah menghidupkan oposisi atau menimbulkan sifat apatis. 


\section{b. Tipe Laissez-faire}

Dalam tipe kepemimpinan ini sebenarnya pemimpin tidak memberikan kepemimpinannya. Dia membiarkan bawahannya berbuat sekehendaknya. Pemimpin sama sekali tidak memberikan kontrol dan koreksi terhadap pekerjaan bawahannya. Pembagian tugas dan kerja sama diserahkan sepenuhnya kepada bawahannya tanpa petunjuk atau saran-saran dari pemimpin. Dengan demikian, mudah terjadi kekacauan-kekacauan dan bentrokan-bentrokan. Tingkat keberhasilan anggota dan kelompok semata-mata disebabkan oleh kesadaran dan dedikasi beberapa anggota kelompok, dan bukan karena pengaruh dari pemimpin. Struktur organisasinya tidak jelas atau kabur, segala kegiatan dilakukan tanpa rencana dan tanpa pengawasan dari pemimpin.

\section{c. Tipe Demokratis}

Gaya kepemimpinan demokratis adalah gaya pemimpin yang memberikan wewenang secara luas kepada para bawahan. Setiap ada permasalahan selalu mengikutsertakan bawahan sebagai suatu tim yang utuh. Dalam gaya kepemimpinan demokratis, pemimpin memberikan banyak informasi tentang tugas serta tanggungjawab para bawahannya.

Pemimpin tipe ini senantiasa ikut berbaur di tengah anggotaanggota kelompoknya. Hubungan pemimpin dengan anggota bukan sebagai majikan dengan bawahan, melainkan lebih seperti kakak dengan saudara-saudaranya. Dalam tindakan dan usaha-usahanya selalu berpangkal pada kepentingan dan kebutuhan kelompoknya serta mempertimbangkan kesanggupan dan kemampuan kelompoknya. Dalam melaksanakan tugasnya, ia mau menerima, bahkan mengharapkan pendapat dan saran-saran dari kelompoknya. Ia mempunyai kepercayaan pula pada anggota-anggotanya bahwa mereka mempunyai kesanggupan bekerja dengan baik dan bertanggungjawab. Ia selalu berusaha membangun semangat anggota kelompok dalam menjalankan dan mengembangkan daya kerjanya dengan cara memupuk rasa kekeluargaan dan persahabatan. Di samping, ia memberi kesempatan kepada anggota kelompoknya agar 
mempunyai kecakapan memimpin dengan jalan mendelegasikan sebagian kekuasaan dan tanggung jawabnya.

\section{d. Tipe Pseudo-demokratis}

Tipe ini disebut juga semi demokratis atau manipulasi diplomatik. Pemimpin yang bertipe pseudo-demokratis hanya tampaknya bersikap demokratis, padahal sebenarnya dia bersikap otokratis. Misalnya, jika ia mempunyai ide-ide, pikiran, atau konsep yang ingin diterapkan di lembaga pendidikannya, hal tersebut akan dibicarakan dan dimusyawarahkan dengan bawahannya, tetapi diatur dan diciptakan sedemikian rupa sehingga pada akhirnya bawahan didesak agar menerima ide atau pikiran tersebut sebagai keputusan bersama. Pemimpin ini menganut demokrasi semu dan lebih mengarah pada kegiatan pemimpin yang otoriter dalam bentuk yang halus, samar-samar, dan yang mungkin dilaksanakan tanpa disadari bahwa tindakan itu bukan tindakan pimpinan yang demokratis.

\section{Kompetensi Pemimpin}

Seorang pemimpin harus memiliki unsur-unsur yang mendasari kesanggupan menjalankan peran kepemimpinannya yang terintegrasi secara utuh dan melekat dalam dirinya. Kemampuan, keterampilan ataupun kompetensi yang harus dimiliki oleh seorang pemimpin/manajer menurut Sarinah, dikategorikan ke dalam; conceptional skill, humanity skill, dan technical skill; a) Keterampilan konseptual (conceptional skill); top manager harus memiliki keterampilan untuk membuat konsep, ide, dan gagasan demi kemajuan organisasi yang kemudian dijabarkan menjadi suatu rencana kegiatan untuk mewujudkan gagasan atau konsepnya itu. Proses penjabaran ide menjadi suatu rencana kerja yang kongkret itu biasanya disebut sebagai proses perencanaan, b) Keterampilan berhubungan dengan orang lain (humanity skill). ${ }^{14}$

${ }^{14}$ Sarinah, Pengantar Manajemen, h. 113. 
Manajer juga perlu dilengkapi dengan keterampilan berkomunikasi atau keterampilan berhubungan dengan orang lain, yang disebut juga keterampilan kemanusiaan. Dengan komunikasi yang persuasif, bersahabat, dan kebapakan akan membuat karyawan merasa dihargai dan kemudian mereka akan bersikap terbuka kepada atasan, c) Keterampilan teknis (technical skill) Keterampilan ini merupakan bekal bagi manajer pada tingkat yang lebih rendah. Keterampilan teknis ini merupakan kemampuan untuk menjalankan suatu pekerjaan tertentu, misalnya menggunakan program komputer, memperbaiki mesin, membuat kursi, akuntansi dan lain-lain.

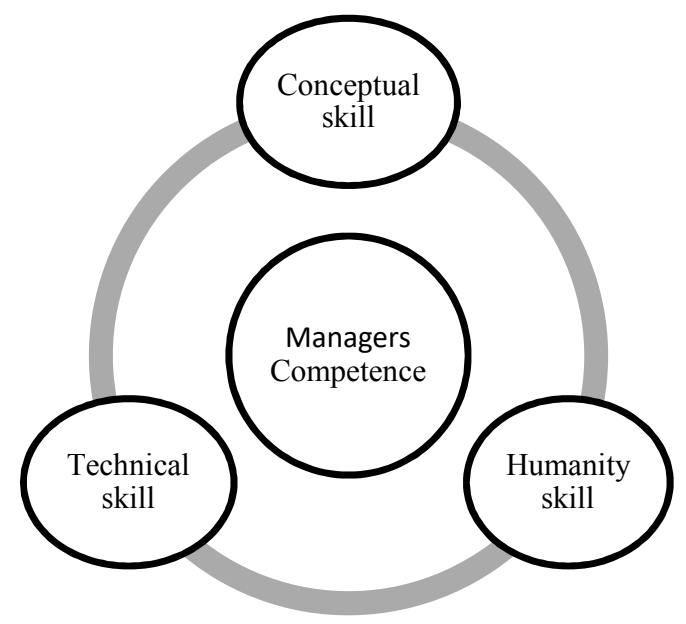

\section{Konsep Ruh al-Jama'ah}

Ruhul jama'ah merupakan frase nominal yang berasal dari bahasa Arab yaitu رُوح الجماعة. Ruhul jama'ah terdiri dari dua unsur kosa kata, yaitu kata ruh dan kata jama'ah. Kata jُوح dalam morfologi Bahasa Arab merupakan bentuk noun verbal (mashdar) dari kata kerja راح yang memiliki banyak arti, antara lain: 1) Kata الرَّوْحُ : الرحمة (rawh) yang 
berarti rahmat, 2) Kata الرُّوُحُ ج أرواح : النفس (ruh) untuk ruh, jiwa, sukma (spiritual), dan 3) Kata الرّيحُ : الريحة (rih) yang berarti angin.

Dengan demikian, kata ruh (رُوح) dalam bahasa Arab digunakan untuk menyebut jiwa, nyawa, nafas, wahyu, perintah dan rahmat. Jika kata ruhani dalam bahasa Indonesia digunakan untuk menyebut lawan dari dimensi jasmani, maka dalam bahasa Arab kalimat الروحيّ والروحابِيُ3 digunakan untuk menyebut rohani (spiritual). ${ }^{15}$

Dalam al-Qur'an, kata ruh digunakan bukan hanya satu arti. Term-term yang digunakan al-Qur'an dalam penyebutan ruh, bermacam-macam, diantaranya ruh disebut sebagai "sesuatu", "Dan mereka bertanya kepadamu tentang roh. Katakanlah: "Roh itu termasuk urusan Tuhan-ku, dan tidaklah kamu diberi pengetahuan melainkan sedikit". (QS. Al-Isra': 85).

Selanjutnya al-Qur'an juga banyak menggunakan kata ruh dengan ruh al-amin, ruh al-quds, ruh saja untuk pengertian;

a) Malaikat Jibril; "Dan sesungguhnya Al Quran ini benar-benar diturunkan oleh Tuhan semesta alam, dia dibawa turun oleh Ar-Ruh AlAmin (Jibril) (Al-Syu'ara': 193). "Dan sesungguhnya Kami telah mendatangkan Al Kitab (Taurat) kepada Musa, dan Kami telah menyusulinya (berturut-turut) sesudah itu dengan rasul-rasul, dan telah Kami berikan bukti-bukti kebenaran (mukjizat) kepada Isa putera Maryam dan Kami memperkuatnya dengan Ruhul Qudus. Apakah setiap datang kepadamu seorang rasul membawa sesuatu (pelajaran) yang tidak sesuai dengan keinginanmu lalu kamu menyombong; maka beberapa orang (diantara mereka) kamu dustakan dan beberapa orang (yang lain) kamu bunuh? (al-Baqarah: 87).

b) Rahmat Allah, kepada kaum mukminin; "Kamu tak akan mendapati kaum yang beriman pada Allah dan hari akhirat, saling berkasih-sayang dengan orang-orang yang menentang Allah dan RasulNya, sekalipun orang-orang itu bapak-bapak, atau anak-anak atau

\footnotetext{
${ }^{15}$ Ahmad Warson M. Al-Munawwir, (Yogyakarta: Pustaka Progressif, 1984), h. 545.
} 
saudara-saudara ataupun keluarga mereka. Mereka itulah orang-orang yang telah menanamkan keimanan dalam hati mereka dan menguatkan mereka dengan pertolongan yang datang daripada-Nya. Dan dimasukanNya mereka ke dalam surga yang mengalir di bawahnya sungai-sungai, mereka kekal di dalamnya. Allah ridha terhadap mereka, dan merekapun merasa puas terhadap (limpahan rahmat)-Nya. Mereka itulah golongan Allah. Ketahuilah, bahwa sesungguhnya hizbullah itu adalah golongan yang beruntung. (Al-Mujadalah: 22)

c) Kitab suci al-Qur'an, "Dan demikianlah Kami wahyukan kepadamu wahyu (Al Quran) dengan perintah Kami. Sebelumnya kamu tidaklah mengetahui apakah Al Kitab (Al Quran) dan tidak pula mengetahui apakah iman itu, tetapi Kami menjadikan Al Quran itu cahaya, yang Kami tunjuki dengan dia siapa yang kami kehendaki di antara hamba-hamba Kami. Dan sesungguhnya kamu benar-benar memberi petunjuk kepada jalan yang lurus. (Al-Shura: 52)

Dalam artikel ini, penulis menggunakan kata ruh untuk pengertian jiwa, sukma, spiritual yang menjadi objek kajian psikologi manajemen melalui pendekatan prilaku manusia dalam organisasi (human behavior approach). Selanjutnya, kata al-‘jamaah' (الجماعة) memiliki beberapa arti. Kamus Hans Wehr, menyebutkan arti kata (الجماعة) sebagai; group (of people); band, gang, party, troop; community; squad (military unit). ${ }^{16}$

Pandangan lainnya datang dari Al-Ra'is dalam karyanya almukhtashar al-syafi halaman 10, memberikan pemaknaan (الجماعة), dari perspektif syariat yang memiliki dua pengertian: 1) jama'ah badan atau fisik, 2) jama'ah agama atau non fisik. Jamaah badan atau fisik merupakan konsep hidup berjamaah di bawah kepemimpinan seorang penguasa yang muslim.

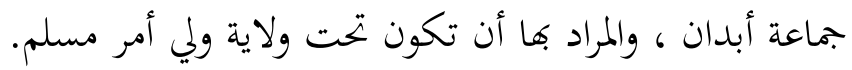

\author{
1971), h. 135.
}


Sedangkan jamaah agama atau non fisik. Inilah pengertian jamaah yang dimaksudkan oleh Ibnu Mas'ud dalam perkataannya "jamaah adalah bersesuaian dengan kebenaran meski engkau sendirian" dan inilah pengertian jamaah dalam hadits tentang perpecahan umat. Nabi bersabda, "Umatku akan berpecah menjadi 73 bagian. Seluruhnya di neraka kecuali satu yaitu al Jamaah", yang dimaksud dengan al Jamaah di sini adalah jamaah al-adyan atau jamaah karena memegang kebenaran yang sama.

$$
\text { ثماعة الأديان ، وعليه يحمل قول ابن مسعود المتقدم و حديث " مستفترق أمتي على }
$$

Dalam al-qur'an disebutkan pengertian jama'ah agama dengan perbandingan antara berpegang teguh pada kebenaran dari Allah atau melepaskan kebenaran itu, "dan berpeganglah kamu semuanya kepada tali (agama) Allah, dan janganlah kamu bercerai berai, dan ingatlah akan nikmat Allah kepadamu ketika kamu dahulu (masa Jahiliyah) bermusuhmusuhan, maka Allah mempersatukan hatimu, lalu menjadilah kamu karena nikmat Allah, orang-orang yang bersaudara; dan kamu telah berada di tepi jurang neraka, lalu Allah menyelamatkan kamu dari padanya. Demikianlah Allah menerangkan ayat-ayat-Nya kepadamu, agar kamu mendapat petunjuk.

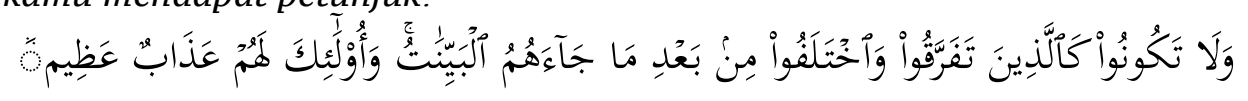

Dan janganlah kamu menyerupai orang-orang yang bercerai-berai dan berselisih sesudah datang keterangan yang jelas kepada mereka. Mereka itulah orang-orang yang mendapat siksa yang berat,

Berdasarkan beberapa pengertian al jamaah di atas, maka dalam tulisan ini, penulis mengambil pengertian jama'ah badan yakni perserikatan orang-orang yang bekerjasama tim dalam sebuah organisasi ataupun lembaga untuk mencapai tujuan organisasi. Upaya menggerakkan orang-orang untuk termotivasi dan bersemangat bekerjasama memerlukan keahlian dan kompetensi (humanity skill) seorang pemimpin yang tidak gampang untuk diterapkan. 


\section{Membangun Ruhul Jama'ah (Teamwork)}

Membangun ruh al jama'ah bagi seorang pemimpin memerlukan kemampuan dan keahlian khusus untuk memahami kondisi dan prilaku manusia, dan masuk ke dalam katagori humanity skill. Kemampuan memahami kondisi psikologis orang atau bawahan, menjadi prioritas sebagaimana yang dimaksudkan oleh Marry Parker Follet dalam mendefenisikan manajemen, "Management is the art of getting things done throught people". Manajemen merupakan seni dalam mencapai tujuan melalui orang lain. ${ }^{17}$

Teamwork atau kerja sama tim merupakan bentuk kerja kelompok yang bertujuan untuk mencapai target yang sudah disepakati sebelumnya. Harus disadari bahwa teamwork merupakan peleburan berbagai kepribadian yang menjadi satu guna mencapai tujuan bersama. Tujuan tersebut bukanlah tujuan pribadi, bukan tujuan ketua tim, bukan pula tujuan dari pribadi paling populer dalam tim.

Dalam sebuah tim yang dibutuhkan adalah kemauan untuk saling bergandeng-tangan menyelesaikan pekerjaan. Bisa jadi, satu orang tidak menyelesaikan pekerjaan atau tidak ahli dalam pekerjaan A, namun dapat dikerjakan oleh anggota tim lainnya. Inilah yang dimaksudkan dengan kerja tim, beban dibagi untuk satu tujuan bersama.

Imajinasi lebih dinamis dalam lingkungan kelompok, disamping memiliki lebih banyak informasi dibandingkan yang dimiliki individu tunggal, kelompok memiliki lebih banyak pengalaman bersama yang dapat digunakan. Bila orang-orang dalam kelompok dapat dibebaskan dari rintangan, kritik diri, dan kritik pihak lain, mereka akan menghasilkan lebih banyak cara penyelesaian masalah yang imajinatif.

Saling mengerti dan mendukung satu sama lain merupakan kunci kesuksesan dari teamwork. Jangan pernah mengabaikan pengertian dan dukungan ini. Meskipun terjadi perselisihan antar pribadi, namun dalam tim harus segera menyingkirkannya terlebih

17 Sulastri, Manajemen, Sebuah Pengantar Sejarah, Tokoh, Teori dan Praktik, (Bandung: La Goods Publishing, 2014), h. 10. 
dahulu. Bila tidak kehidupan dalam tim jelas akan terganggu. Bahkan dalam satu tim bisa jadi berasal dari latar belakang divisi yang berbeda yang terkadang menyimpan pula perselisihan. Makanya sangat penting untuk menyadari bahwa kebersamaan sebagai anggota tim di atas segalanya.

Pada dasarnya sewaktu Pemimpin menjalankan pekerjaan mereka, mereka akan selalu melakukan sejumlah perencanaan, pengorganisasian, pengarahan dan pengendalian. "Pembahasan dalam ilmu manajemen yaitu meliputi perencanaan (planning), pengorganisasian (organizing), pengarahan (directing) dan pengendalian (controlling)". ${ }^{18}$

Pengarahan (directing/leading) biasanya dikatakan sebagai kegiatan manajemen yang paling menantang dan paling penting karena langsung berhadapan dengan manusia. Bagaimana membuat orang lain bekerja untuk tujuan organisasi merupakan pekerjaan yang tidak mudah. Manajer harus mampu menciptakan suasana (atmosfer) yang bisa mendorong orang untuk bekerja dan bekerjasama. Lebih spesifik lagi pengarahan meliputi kegiatan memberi pengarahan (directing), memengaruhi orang lain (influencing), dan memotivasi orang tersebut untuk bekerja (motivating).

\section{Memberi Pengarahan (directing)}

G.R. Terry dalam mengemukakan "Actuating is setting all members of the group to want to achieve and to strike to achieve the objective willingly and keeping with the managerial planning and organizing efforts. (pengarahan adalah membuat semua anggota kelompok agar mau bekerja sama dan bekerja secara ikhlas serta bergairah untuk mencapai tujuan sesuai dengan perencanaan dan usaha-usaha pengorganisasian), lalu Koontz dan O'Donnel mengatakan "directing and leading are the interpersonal aspects of managing by which subordinate are lead to understand and contribute effectively and efficiency to the attainment of enterprise objectives". (pengarahan adalah hubungan antara aspek-aspek individual yang

${ }^{18}$ Sarinah, Pengantar Manajemen, h. 2. 
ditimbulkan oleh adanya pengaturan terhadap bawahan-bawahan untuk dapat dipahami dan pembagian kerja yang efektif dan efesien untuk tujuan perusahaan yang nyata). ${ }^{19}$

Oleh karena itu, upaya membangun ruh al jama'ah diawali dengan menjalankan fungsi pengarahan dan penjelasan peran hubungan antar personal maupun peran dan hubungan antara personal dengan pimpinan agar difahami batas dan wewenang serta tanggungjawab masing-masing dalam organisasi serta menyuntikkan rasa keikhlasan dalam bekerja dan bekerjasama.

\section{Mempengaruhi Orang Lain (influencing)}

Pemimpin adalah penggerak sebuah atau beberapa buah kelompok. Untuk dapat mengerakkan kelompok, ada kesepakatankesepakatan yang harus dijalin dalam dan dengan kelompok, Personal behavior pimpinan dan keterampilan yang dijalankan harus terangkum di dalam diri sosok pemimpin. Untuk meningkatkan efektifitas kepemimpinannya, pemimpin dapat menggunakan pengaruh: (a) rational persuasion, menggunakan argumen-argumen yang logis dan data-data faktual untuk membujuk orang-orang, dimana permintaanpermintaan yang diajukan dapat berjalan dan menghasilkan keluarankeluaran yang diharapkan, (b) exchange tactics, permintaan yang diajukan berupa janji yang secara eksplisit atau implisit menyediakan hadiah pada orang-orang yang menjadi target, (c) legitimate request, basis dari permintaan dengan menggunakan fasilitas kewenangan atau aturan-aturan, dan disesuaikan dengan peraturan-peraturan organisasi, kebijakan, dan kegiatan- kegiatan yang dijalankan, (d) pressure tactics, melalui perlakuan yang secara eksplisit atau implisit memuat ketentuan bahwa kesalahan yang terjadi memiliki konsekuensi-konsekuensi tertentu, dan (e) personal eppeals, menggunakan sisi hati orang lain dan perkawanan secara personal berbagai basis dari permintaan-permintaan. ${ }^{20}$

\footnotetext{
${ }^{19}$ Badrudin, Dasar-dasar Manajemen, h. 152.

${ }^{20}$ El-Widdah, Kepemimpinan Berbasis Nilai, h. 46.
} 


\section{Memotivasi (motivating)}

Sebagaimana telah disebutkan pada pendahuluan artikel ini, bahwa perilaku kepemimpinan itu ada yang berorientasi pada tugas (job centered production orientation) dan ada pula yang berorientasi pada karyawan (employee centered/employee orientation). Perilaku yang berorientasi pada tugas (job centered production orientation) merupakan perilaku yang menunjukkan dengan tegas pola-pola hubungan antara pemimpin dengan yang dipimpin, menjelaskan bagaimana pola-pola organisasi yang ada, saluran-saluran komunikasi, dan cara-cara dalam menjalankan semua pekerjaan yang ada dalam organisasi. Sedangkan pola-pola perilaku yang berorientasi pada karyawan (employee centered/employee orientation) mengacu pada perilaku yang menunjukkan hubungan bersahabat, saling memegang kepercayaan, kehangatan, perhatian, dan respek dalam hubungan antara pemimpin dengan yang dipimpinnya.

Perilaku yang berorientasi pada tugas (job centered production orientation) mengandung ciri-ciri sebagai berikut: (1) mengutamakan tercapainya tujuan; bahwa pemimpin mengarahkan bawahannya melalui tugas-tugas yang harus dikerjakan oleh bawahan kearah pencapaian tujuan yang harus dicapai, 2) pemimpin lebih mementingkan ketercapaian dari sisi produksi atau layanan yang tinggi, (3) tugas pemimpin pada bawahan lebih banyak pada proses pengarahan pekerjaan, tugas dan tanggungjawab yang harus dilakukan oleh bawahan, (4) proses kegiatan yang dilakukan oleh bawahan dan segala aktivitas bawahan dilakukan pengawasan yang ketat oleh pimpinan 5) penilaian dilakukan oleh pimpinan atas tugas dan tanggungjawab bawahan dilakukan semata-mata berdasarkan hasil tugas yang telah dikerjakan.

Dalam membangun ruh al jama'ah, pendekatan Perilaku kepemimpinan yang berorientasi pada memahami perilaku bawahan atau karyawan (employee centered/employee orientation) menjadi alternative yang paling memungkinkan untuk diterapkan. Pendekatan ini mengandung ciri-ciri sebagai berikut: (1) pimpinan dalam pelaksanaan tugasnya memperhatikan kebutuhan bawahan, pimpinan berusaha menciptakan suasana saling percaya antar 
bawahan dengan pimpinan dan bawahan dengan bawahan, (3) pimpinan menaruh simpati terhadap bawahan sebagai bagian dari organisasi, (4) pimpinan memperlihatkan sisi persahabatan dengan bawahan, (5) pimpinan lebih mengutamakan pengarahan diri, mendisiplin diri, mengontrol diri.

Pada dasarnya manusia termotivasi untuk memenuhi kebutuhan yang paling penting baginya pada waku tertentu. Adanya keseimbangan kebutuhan, menyebabkan timbulnya dorongan motivasi. Menurut teori motivasi Abraham Maslow dalam kebutuhan manusia dikelompokkan dalam lima tingkat hirarki, yaitu: 1)Kebutuhan fisiologis, seperti sandang, pangan, perumahan, seks, dan sebagainya, 2) Kebutuhan rasa aman dan perlindungan (safety and security) sehingga terjamin keamanannya, 3) Kebutuhan sosial (social needs), yang meliputi kebutuhan akan dicintai, diperhitungkan sebagai pribadi, diakui sebagai anggota kelompok, rasa setia kawan, dan kerjasama, 4) Kebutuhan akan penghargaan (esteem needs) termasuk kebutuhan dihargai karena prestasi, memiliki kemampuan, kedudukan atau status, pangkat, dan sebagainya, 5) Kebutuhan aktualisasi diri (self actualization), seperti kebutuhan mempertinggi potensi-potensi yang dimiliki, pengembangan diri secara maksimai, kreativitas dan ekspresi dan lain sebagainya.Teori Maslow ini efektif bila di implementasikan untuk membangun kerjasama tim secara optimal. ${ }^{21}$

Banyak tulisan para motivator dan para leader dalam membangun kerja sama tim yang berlandaskan pada teori kebutuhan Abraham Maslow tersebut di atas, sebagaimana yang telah dipublikasikan pada situs https://www.finansialku.com/caramembangun-kerja-sama-tim/, yang memaparkan 7 rahasia cara membangun kerja sama tim yang kompak di perusahaan sebagai berikut: ${ }^{22}$

${ }^{21}$ Baharuddin, Manajemen Pendidikan Islam, (Malang: UIN Maliki Malang, 2006), h. 51 .

22 https://www.finansialku.com/cara-membangun-kerja-sama-tim/. Diakses 22 Agustus 2019. 


\section{Tanamkan Visi Misi Perusahan Pada Anggota Tim}

Seorang pemimpin perusahaan atau setidaknya ketua sebuah divisi, seharusnya menanamkan visi misi perusahaan kepada para anggota tim agar mereka bekerja melakukan tanggung jawab mereka dengan memiliki tujuan sesuai dengan arahan perusahaan yang dipimpin. Seorang bawahan yang bertanggung jawab, akan berkiblat pada tujuan perusahaan dalam memenuhi setiap tugas pekerjaannya, walaupun posisi jabatannya tidak terlalu tinggi.

\section{Menghargai Perbedaan Pendapat}

Perbedaan pendapat memang biasa. Setiap orang memiliki ide masing-masing dan cara yang berbeda dalam melakukan tugasnya dalam memenuhi sebuah tujuan. Kerap terjadi dalam sebuah tim jika seorang anggota sangat teguh berpegang pada ide yang ia sampaikan sehingga tidak mengindahkan berbagai ide kreatif lainnya dari rekan satu tim. Terkadang, ada kalanya rasa kecewa timbul jika ide yang kita sampaikan tidak diterima sebagai keputusan bersama dalam tim. Namun, inilah keputusan kelompok.

\section{Saling Percaya}

Dalam sebuah organisasi, tidak jarang timbul saling sikut karena menginginkan kenaikan jabatan dan tentu saja kenaikan gaji. Tak jarang kerap timbul perselisihan dan timbul rasa tidak percaya. Atmosfer kerja seperti ini sangatlah tidak sehat dan sudah dipastikan kehancuran tim akan terjadi. Jika Anda adalah seorang pemimpin dalam perusahaan tersebut, gunakan wewenang Anda sebijak mungkin. Ada baiknya Standard Operational Procedure (SOP) yang seimbang antara bagian atau divisi sehingga tidak ada ketimpangan atau ketidakseimbangan pembagian tugas dan tanggung jawab.

\section{Lakukan Komunikasi yang intensif dan Efektif}

Komunikasi memang tidak dapat dianggap sepele. Komunikasi yang tidak berhasil akan membuat suatu hubungan menjadi renggang. Lakukan komunikasi yang intensif dengan setiap anggota tim dengan mengadakan meeting atau setidaknya pertemuan untuk melakukan koordinasi tugas harian, briefing tugas secara singkat dan juga evaluasi 
kinerja harian atau mingguan. Setiap laporan dan aspirasi perlu ditampung dengan baik dan pecahkan setiap masalah dengan melakukan case study secara bersama-sama. Libatkan seluruh anggota tim dalam melakukan pemecahan masalah (problem solving).

\section{Adakan Kegiatan Bersama}

Hubungan antar anggota perlu dipupuk dengan kegiatankegiatan kebersamaan, baik itu diadakan di dalam kantor atau saat hari di luar kegiatan kantor. Mengadakan kegiatan makan bersama di salah satu rumah anggota tim bisa menjadi salah satu pilihan. Ide itu akan sangat menolong dalam membangun kerja sama tim yang semakin solid.

\section{Saling Menghargai Kinerja Antar Kelompok}

Jika Anda seorang atasan, jangan enggan untuk mengatakan pujian kepada bawahan anda yang melakukan prestasi sekecil apapun. Rasa penghargaan yang Anda berikan bahkan sebuah kata "terima kasih atas kerja dan usahanya”, dapat membuatnya semakin percaya diri dan juga timbul rasa ingin bekerja lebih maksimal dari sebelumnya.

\section{Tingkatkan Kompetensi Anggota Tim}

Dengan meningkatnya kompetensi para anggota tim, semakin tinggi juga kinerja yang mereka lakukan. Jika Anda seorang atasan, fasilitasi bawahan Anda untuk dapat mengembangkan diri mereka untuk mendapatkan kompetensi yang semakin meningkat melalui seminar dan pelatihan. Izinkan juga mereka untuk meningkatkan edukasi jika ada di antara anggota tim Anda yang ingin melanjutkan jenjang studi mereka.

\section{KESIMPULAN}

Kesanggupan dan kompetensi menjalankan fungsi manajemen merupakan syarat mutlak yang harus dimiliki oleh seorang pemimpin. Selain itu, gaya kepemimpinan turut serta mempengaruhi kehidupan organisasi kearah yang lebih humanis, karena sumber daya manusia 
yang menjadi salah satu unsur organisasi dan merupakan urat nadi bagi keberlangsungan organsisasi ataupun Lembaga tersebut.

Sebagai kumpulan orang-orang yang beraktivitas, suatu organsisasi perlu dikelola dengan manajemen, diarahkan dan dimotivasi dengan menerapkan fungsi leadership seorang pemimpin agar seluruh elemen yang ada di dalamnya berjalan on the track mencapai tujuan organisasi secara efektif dan efesien. Teamwork atau kerja sama tim merupakan bentuk kerja kelompok yang bertujuan untuk mencapai target yang sudah disepakati dalam organisasi. Seorang pemimpin harus mampu menciptakan "atmosfer" kehidupan organisasi yang mampu mendorong orang untuk bekerja dan bekerjasama melalui kegiatan memberi pengarahan (directing), mempengaruhi orang lain (influencing), dan memotivasi orang tersebut untuk bekerja (motivating).

Untuk meningkatkan efektifitas kepemimpinannya, pemimpin dapat menggunakan pengaruh: (a) rational persuasion, (b) exchange tactics, (c) legitimate request, (d) pressure tactics, dan (e) personal appeals. Termasuk juga; (f) memperhatikan kebutuhan bawahan (teori Abraham Maslow), (g) menciptakan suasana saling percaya antar bawahan dengan pimpinan dan bawahan dengan bawahan, (g) menaruh simpati terhadap bawahan sebagai bagian dari organisasi, (h) memperlihatkan sisi persahabatan dengan bawahan, (i) dan mengutamakan pengarahan diri, mendisiplin diri, mengontrol diri.

\section{Daftar Pustaka}

Akdon, Strategic Management for Educational Management. Bandung: Alfabeta, 2009.

Ahmad Warson M, Al-Munawwir, Yogyakarta: Pustaka Progressif, 1984.

Badrudin, Dasar-dasar Manajemen. Bandung: Alfabeta, 2015. , Manajemen Pendidikan Islam. Malang: UIN Maliki Malang, 2016. 
Dan B. Curtis dkk, Komunikasi Bisnis dan Profesional. Bandung: Remaja Rosdakarya, 2006.

Minnah El Widdah, Kepemimpinan Berbasis Nilai dan Pengembangan Mutu Madrasah. Bandung: Alfabeta, 2012.

Hans Wehr, A Dictionary of Modern Written Arabic. London: Otto Harrassowitz, 1971.

https://www.finansialku.com/cara-membangun-kerja-sama-tim/.

Karlof and Lovingsson, The A-Z of Management Concepts and Models. India: Replika Press, 2005.

Muhaimin dkk, Manajemen Pendidikan, Aplikasinya dalam Penyusunan Rencana Pengembangan Sekolah/Madrasah, Jakarta: PT Kharisma Putra Utama, 2009.

Musfah, Manajemen Pendidikan, teori, kebijakan, dan praktek, Jakarta: Kencana, 2017.

Endin Nasrudin, Psikologi Manajemen. Bandung: Pustaka Setia, 2018.

Andi Rasyid Pananrangi, Manajemen Pendidikan. Jakarta: Celebes Media Perkasa, 2017.

Sarinah, Pengantar Manajemen, Yogyakarta: Deepublish, 2017.

Sulastri, Manajemen, Sebuah Pengantar Sejarah, Tokoh, teori dan Praktik. Bandung: La Goods Publishing, 2014.

Terry and Rue, Dasar-dasar Manajemen, Jakarta: Bumi Aksara, 2019. 